\title{
New Communication Technologies: \\ Understanding How Intranets and the Internet Can Be Used By Organizations
}

\author{
Catherine A. Middleton \\ Schulich School of Business \\ York University \\ Toronto, Canada \\ cmiddlet@yorku.ca
}

This paper was presented at the Third Americas Conference on Information Systems, August 1997, Indianapolis, USA.

This is a condensed version of the paper. It was published in this format in the conference proceedings, and should be cited as:

Middleton, C. A. (1997). "New Communication Technologies: Understanding How Intranets and the Internet Can Be Used By Organizations.” In J. N. D. Gupta (Ed.), Proceedings of the Third Americas Conference on Information Systems, (pp. 188-190). Indianapolis, IN: Association for Information Systems.

The full version of this paper is available as a Schulich School of Business working paper, and can be downloaded from www.yorku.ca/cmiddlet/pubs/21-97.pdf 
Catherine A. Middleton (cmiddlet@yorku.ca)

Schulich School of Business, York University, 4700 Keele Street, North York, Ontario, Canada M3J 1P3

\title{
New Communication Technologies: Understanding How Intranets and the Internet Can Be Used By Organizations
}

\begin{abstract}
This paper outlines seven actions recommended for businesses considering the establishment of an intranet or Internet presence. It places emphasis on understanding business communication needs, and indicates how they can be met with a variety of electronic communication technologies.
\end{abstract}

Electronic communication technologies, like the Internet, offer businesses significant new ways of communicating (Huber, 1989; Thompson, 1975). Specifically, there are four features that distinguish new electronic communication technologies from existing communications technologies. These are i) high level capacity for data storage and transmission speed, combined with easy access to stored data; ii) creation of a new shared space in which communication can occur, enabling contact between individuals and groups who might otherwise have never communicated; iii) capacity for widespread idea dissemination or targeted communication, combined with interactivity and multi-directional information flows; and iv) improved communication abilities over time and space, rendering geographic location unimportant. These features impact upon organizations, leading to changes in organizational structure and culture (Morgan, 1988; Sproull \& Kiesler 1991; Stewart, 1994).

Given that the adoption of new communication networks (NCNs) can significantly change business communication patterns and operational environments, the decision to adopt such technologies should not be made casually. Furthermore, although the purpose of adopting such technologies is likely to be to conduct electronic commerce, businesses must understand that these technologies are first and foremost communication media. Thus, selling goods on the web is primarily a matter of information exchange between two or more parties. Likewise, advertising products and services, or providing on-line customer support are other examples of businesses communicating information to their clients. To really understand the business potential of the Internet and corporate intranets, it is crucial that their significance as communication tools be understood. This paper outlines seven actions businesses can take to assess their current usage of new communication networks, and to determine whether investments in additional network activities are desirable for their own organizations.

1. Determine reasons for using new communication networks. Although organizations can't predict exactly how business initiatives on the Internet or an intranet will be received, they should have strong notions of why the initiatives are being undertaken. Measurable objectives should be drawn up, and regular progress assessments should be implemented. The implications of running parallel or similar services on and off the Internet should be considered before offering Internet services.

2. Identify the technologies required to enact business objectives. What are the primary goals of the NCN initiative(s)? Should an Internet presence be established, or will an intranet suffice? Table 1 below helps address these issues, outlining a variety of technologies that can be deployed to satisfy various communication requirements.

It is important for a business to understand what it wants to achieve, and with whom it is communicating, before making decisions as to which communication technologies are most appropriate. For those businesses whose communication needs are primarily internal, an Internet presence is not necessary, but an intranet may be invaluable. For those with limited external communication (e.g. with a select group of customers or suppliers) LANs or WANs (wide area networks) may suffice. But for those wanting to make and maintain contact with a wide base of clients and suppliers, the Internet is likely to be the medium of choice. The Internet is now a defacto public communication system, which means that it can be used for a wide variety of corporate communication tasks. The challenge for businesses is to understand the nature of their communications (e.g. one sender to one receiver, one sender to many receivers, public or private access) before selecting the communication technologies they will adopt. 
Table 1: Internal and External Communication Technologies and their Uses

\begin{tabular}{|l|l|l|l|l|}
\hline $\begin{array}{l}\text { Communication } \\
\text { Requirement }\end{array}$ & $\begin{array}{l}\text { Nature of Sender and } \\
\text { Receiver(s) }\end{array}$ & Internal Activities & $\begin{array}{l}\text { Internal/External } \\
\text { i.e. limited external } \\
\text { access) }\end{array}$ & $\begin{array}{l}\text { External Activities } \\
\text { (i.e. public access) }\end{array}$ \\
\hline \hline $\begin{array}{l}\text { Interpersonal } \\
\text { Communication }\end{array}$ & One to One & $\begin{array}{l}\text { LAN or Internet e- } \\
\text { mail }\end{array}$ & $\begin{array}{l}\text { LAN, WAN or } \\
\text { Internet e-mail }\end{array}$ & Internet e-mail \\
\hline $\begin{array}{l}\text { Text-Based Information } \\
\text { Sharing \& Discussion }\end{array}$ & $\begin{array}{l}\text { One to One, One to } \\
\text { Many, Many to Many }\end{array}$ & $\begin{array}{l}\text { Groupware (e.g. } \\
\text { LotusNotes), Intranet }\end{array}$ & Groupware, Intranet & $\begin{array}{l}\text { Public Access BBS (e.g. } \\
\text { CompuServe), Usenet, } \\
\text { Internet Mailing Lists }\end{array}$ \\
\hline $\begin{array}{l}\text { File -Based Information } \\
\text { Sharing \& Retrieval }\end{array}$ & $\begin{array}{l}\text { One to One, Many to } \\
\text { One }\end{array}$ & $\begin{array}{l}\text { Databases shared via } \\
\text { LAN, Intranet, } \\
\text { Groupware }\end{array}$ & $\begin{array}{l}\text { LAN/WAN, Limited } \\
\text { Access FTP, Intranet }\end{array}$ & FTP, Gopher over Internet \\
\hline $\begin{array}{l}\text { Information } \\
\text { Dissemination (e.g. } \\
\text { advertising, marketing) }\end{array}$ & $\begin{array}{l}\text { One to Many, Many } \\
\text { to Many }\end{array}$ & $\begin{array}{l}\text { Mailing lists, } \\
\text { Intranet }\end{array}$ & $\begin{array}{l}\text { WWW, Internet } \\
\text { mailing lists }\end{array}$ & $\begin{array}{l}\text { WWW, Usenet, Public } \\
\text { Access BBS, Internet } \\
\text { Mailing lists }\end{array}$ \\
\hline $\begin{array}{l}\text { Information Gathering } \\
\text { (serendipitous or } \\
\text { deliberate) }\end{array}$ & $\begin{array}{l}\text { One to Many, Many } \\
\text { to One, Many to } \\
\text { Many }\end{array}$ & $\begin{array}{l}\text { LAN or Internet e- } \\
\text { mail, Intranet, } \\
\text { Executive } \\
\text { Information System }\end{array}$ & $\begin{array}{l}\text { LAN, WAN or } \\
\text { Internet e-mail, } \\
\text { Limited Access } \\
\text { WWW }\end{array}$ & $\begin{array}{l}\text { Internet e-mail, WWW, } \\
\text { Bsenet, Public Access } \\
\text { BBS }\end{array}$ \\
\hline
\end{tabular}

3. Identify the characteristics of users in target markets for NCN activities. If good business reasons exist to establish a web site, it is important to consider the target audience. Do the prospective customers have easy access to the web? Are target customers web users? For example, baby boomers comprise the largest segment of consumer markets (Foot, 1996) but it is uncertain whether they are well-represented in the electronic community. For customers who are known to be using the Internet, is their access by modem? Will all internal users have high speed access to an intranet?

4. Assess network technologies currently in use in the organization. Does the business already have an Internet site? Is there an intranet in use? How effectively do these networks meet their stated objectives? What monitoring systems are in place to assess these networks? Who is in charge of the networks? If these questions cannot be answered then businesses must assess their overall information systems infrastructure and ensure that qualified employees are put in place to manage corporate information technology.

5. Match user characteristics and business objectives, revising existing network use if necessary. If target network users are primarily individuals who access an Internet site by modem, but the site is graphics-laden and accessible only by the latest version of browser software it would not be a surprise to find that the site is ineffective. It is essential to understand how consumers will be accessing a site, and to offer them options that will facilitate their use of the site. In the world of electronic commerce, one size does not fit all. Services or products offered through a NCN must be more convenient to access than by conventional means, otherwise the networks will be bypassed.

6. Ensure that a network management team is in place and has the necessary skills to operate an intranet or Internet site. A network management plan should be established to address such issues as network security, maintenance and technology upgrades. Which department will support proposed Internet services? Is the Internet function seen as a technical responsibility, or one to be handled by a sales, marketing or public relations group? Which individuals will be responsible for development and maintenance of Internet services?

7. Be prepared to deal with the structural impacts of introducing new technologies. Management at all levels must understand the nature of new communication networks and their implications at both the technological and organizational levels. Businesses must be prepared to make structural adaptations, and to expect to undergo cultural changes if their new communication strategies are to succeed.

Table 2 summarizes key issues for businesses considering introducing new information networks or Internet technologies into their organizations. 
Table 2: $\quad$ Key Issues for Businesses Adopting New Communication Technologies

\begin{tabular}{|c|c|}
\hline Business Issues & Organizational Issues \\
\hline $\begin{array}{l}\text { - What are the reasons for introducing new technologies? } \\
\text { - What technologies are appropriate? }\end{array}$ & $\begin{array}{l}\text { - Who will administer and maintain the new } \\
\text { communication services? } \\
\text { - What impacts will the new technologies have upon } \\
\text { organizational culture and structure? }\end{array}$ \\
\hline People Issues & Technology Issues \\
\hline $\begin{array}{l}\text { Who is the target audience for the new communication } \\
\text { media? } \\
\text { - How will employees react to the new technologies? }\end{array}$ & $\begin{array}{l}\text { What types of technologies do targeted users have } \\
\text { access to? Will services offered be easily accessible by } \\
\text { consumers? } \\
\text { - What level of services is needed? } \\
\text { - How will network security be ensured? }\end{array}$ \\
\hline
\end{tabular}

The adoption of new communication networks is predicted to have multiple implications for businesses, ranging from changes in organizational culture and structure, to the adoption of new communication patterns inside and outside the organization, to the decreasing importance of geographic location in doing business, to increased access to shared knowledge and experience.

Accepting that new communication networks are here to stay, businesses must learn to use them effectively. Businesses should not rush onto the Internet just because their competitors are there, they must have clear and compelling business reasons to do so. The use of new communication technologies must be consistent with overall business strategies. Understanding that Internet access is limited, it would be foolish to discontinue marketing, sales and communication efforts that do not take place on the Internet. Organizations must carefully meld their Internet and non-Internet activities.

Key issues when adopting new communication technologies are summarized in Table 2. It is noted that the key to success in using new communication technologies is to have a good understanding of what individual technologies can offer. Not all businesses currently need to have a presence on the Internet. With an understanding of the capabilities of various communication technologies (as provided in Table 1), businesses should match their electronic communication activities to the services currently available.

Finally, it is noted that the Internet as we currently know it will undergo significant change. Does this mean that the conclusions drawn here will be invalid in a month's or a year's time? Fortunately, this is not the case, as the important lessons from this paper apply beyond the specific new communication technologies currently in use. Businesses must always seek to understand new technologies before they implement them, taking care to establish that the technologies are in fact significantly different from those that went before, if they are offered as new technologies that will change the ways businesses operate. Organizations must consider how they could best use the technologies within their own organizational contexts, understanding that not all technologies are appropriately deployed in all organizations. If it is decided that a new technology is appropriate in a given organization, care must be taken to implement it so that it serves its desired purpose, and it must be subject to evaluation, to ensure that the technology is functioning as intended. With these suggestions in hand, organizations should be better equipped to evaluate and implement new communication technologies.

\section{References}

Foot, D. K. (1996). Boom, Bust \& Echo. Toronto: McFarlane Walter Ross.

Huber, G. P. (1989). "A Theory of the Effects of Advanced Information Technologies on Organizational Design, Intelligence, and Decision Making." Academy of Management Review, 15 (1), 47-71.

Morgan, G. (1988). Riding the Waves of Change. San Francisco: Jossey-Bass.

Sproull, L. S., \& Kiesler, S. B. (1991). Connections - New Ways of Working in the Networked Organization. Cambridge, MA: MIT Press.

Stewart, T. A. (1994). "Managing in a Wired Company." Fortune, 130 (11 July), 44-56.

Thompson, G. B. (1975). "An Assessment Methodology for Evaluating Communications Innovations." IEEE Transactions of Communications, 23 (10), 1045-1054. 